\title{
Climatic changes and their role in emergence and re-emergence of diseases
}

\author{
Amr El-Sayed ${ }^{1} \cdot$ Mohamed Kamel $^{1}$
}

Received: 26 February 2020 / Accepted: 14 April 2020 / Published online: 28 April 2020

(C) Springer-Verlag GmbH Germany, part of Springer Nature 2020

\begin{abstract}
Global warming and the associated climate changes are predictable. They are enhanced by burning of fossil fuels and the emission of huge amounts of $\mathrm{CO}_{2}$ gas which resulted in greenhouse effect. It is expected that the average global temperature will increase with $2-5{ }^{\circ} \mathrm{C}$ in the next decades. As a result, the earth will exhibit marked climatic changes characterized by extremer weather events in the coming decades, such as the increase in temperature, rainfall, summertime, droughts, more frequent and stronger tornadoes and hurricanes. Epidemiological disease cycle includes host, pathogen and in certain cases intermediate host/vector. A complex mixture of various environmental conditions (e.g. temperature and humidity) determines the suitable habitat/ecological niche for every vector host. The availability of suitable vectors is a precondition for the emergence of vector-borne pathogens. Climate changes and global warming will have catastrophic effects on human, animal and environmental ecosystems. Pathogens, especially neglected tropical disease agents, are expected to emerge and re-emerge in several countries including Europe and North America. The lives of millions of people especially in developing countries will be at risk in direct and indirect ways. In the present review, the role of climate changes in the spread of infectious agents and their vectors is discussed. Examples of the major emerging viral, bacterial and parasitic diseases are also summarized.
\end{abstract}

Keywords Climate $\cdot$ Climate change $\cdot$ Global warming $\cdot$ Disease $\cdot$ Vector $\cdot$ Mosquitoes $\cdot$ Tick $\cdot$ Sandflies $\cdot$ West Nile $\cdot$ Lyme $\cdot$ Malaria $\cdot$ Zika $\cdot$ Ticks $\cdot$ Tick-borne diseases $\cdot$ Emerging and resurging pathogens $\cdot$ Zoonoses $\cdot$ Vector ecology

\section{Introduction}

According to the World Health Organization (WHO), the "climate change and global warming" are the greatest challenges of humanity in the twenty-first century. They threaten all aspects of our life (Organization WH 2018). Climate change and global warming are two expressions which are usually used in an interchangeable manner although global warming is just one aspect of various aspects associated with climate change. The expression "global warming" usually refers to the observed rise in average global temperature in the last decades in terms of frequency and intensity. It is induced by the greenhouse effect due to the increase in $\mathrm{CO}_{2}$ emissions produced by the increasing consumption of fossil fuels worldwide in

Responsible editor: Lotfi Aleya

Mohamed Kamel

m_salah@staff.cu.edu.eg

1 Department of Medicine and Infectious Diseases, Faculty of Veterinary Medicine, Cairo University, Giza, Egypt parallel with cutting trees/forests. The rise in temperature increases toward the poles and is less near the equator. It accelerates with time and is expected to be faster in the next years and may range between +1.6 and $+6{ }^{\circ} \mathrm{C}$ according to the computer simulator scenarios (IPC C 2001; IPPC 2017; Jimenez-Clavero 2012; Solomon et al. 2007). The global warming-related changes in disease epidemiology are associated with changes in ecosystems, population susceptibility and increased exposure to causative agents (Ghazali et al. 2018). Global warming also affects the geographical distribution of vectors/intermediate host distribution, including invertebrate hosts (insects), rodents and migratory birds. As an example, the zoonotic bacteria pathogen (Chlamydia) can be carried by birds and infects 92 million people annually according to the WHO. The zoonotic bacteria pathogen can be carried by birds and infects 92 million people annually according to the WHO. The disease is associated with bird movement and migration which is, in turn, influenced by the climatic and ecological changes (Geisler 2012) On the other hand, the term "climate change" refers to observed measurable changes of the climate over a long period of time. Climatic changes are 
characterized by extremer weather events, accompanied by the increase in the prevalence of droughts, heat waves, extreme rainfalls and floods or dryness and water scanty, dust storms, tropical cyclones (typhoons or hurricanes), wildfires, melting of snow and disappearance of river delta and coastal cities in addition to environmental changes such as habitat fragmentation, bushmeat consumption, urbanization and deforestation (Handmer et al. 2012; Nava et al. 2017). The negative effects of global warming and climatic changes on human health are largely underestimated. It is estimated that $34 \%$ of all childhood illness and $36 \%$ of young children's deaths worldwide are linked to changes in the environmental factors. Outbreaks of cholera, fatal malaria, diarrhoea or dengue fever are all strongly influenced by climatic changes (Thompson et al. 2012).

Climatic changes can result in change of human sociodemographics (Fig. 1) and massive migration of humans and domestic livestock from dry hot areas to new geographic districts where the life circumstances are better (El-Sayed and Awad 2018). This is accompanied with changes in the classical geographical distribution of wild animals, insects, rodents, and their population worldwide (Mor et al. 2018). The interaction and the epidemiological relationship between climatic changes, environmental and ecosystem disturbance, exposure to vector insects and spread of infectious disease is well documented (Greer et al. 2008; Organization WH 2005; Teklehaimanot et al. 2004). Understanding this link enables the prediction of the expected effects of climatic changes in the near future on the ecology of infectious agents, the spread of pathogens, vectors (intermediate hosts), reservoir animals, and final hosts (Medone et al. 2015).

One of the absolutely underestimated threats of global warming is the melting of ice layer existing since thousands of years. Melting ice will not only lead to the disappearance of many cities and river delta but will also reactivate frozen biological materials stored in frozen soil. Melting of ice layer will not only provide us with buried carcasses of animals since thousands of years like mammoth, but unfortunately, additional hidden biological materials are also buried under snow. In 2012, Virola virus was detected in a 300 old frozen mummy in Siberian (Biagini et al. 2012). While scientists from NASA in 2005 could revive bacteria stored frozen in Alaska since 32,000 years, others could isolate 8-million-year-old bacteria from ice samples in Antarctica (Bidle et al. 2007). Viable bacteria could also be isolated from ice sample 25,000 years old (Katayama et al. 2007) and from Dominican amber (2040 million years old) (Greenblatt et al. 1999). In 2016 in Siberian, a 12-year-old child died and 20 persons were hospitalized due to anthrax infections. The spores were hidden over 75 under frozen soil before being liberated as the ice melt. Anthrax is caused by Bacillus anthracis, a spore-forming bacterium. The spores are very resistant in the environment and can survive/persist for a hundred years in a dormant form. The spores can be transported by floods or by insects (e.g. tabanid flies). Following the same concept, it is imaginable that smallpox virus could also be stored frozen in frozen human bodies buried in frozen soil in Siberian where a large epidemic of small pox occurred in 1890 (Antonenko et al. 2013; Mor et al. 2018).

The WHO listed the health hazards on human health due to climatic changes into the following item (Fig. 2): (1) direct and indirect effects of global warming, (2) stratospheric ozone depletion, (3) disturbance in terrestrial and marine ecosystems, (4) loss of biodiversity, (5) changes in the hydrological systems and freshwater supply, (6) Land degradation and loss of river deltas and coastal cities, (7) urbanization, deforestation and population dislocation/immigration, and finally (8) limited food production (WHO 2017). These direct and indirect effects of the climatic shift on human/animal health and welfare include: (1). The direct influences result from physiopsychological effects from the increased number and duration of heat waves leading to stress, respiratory, circulatory
Fig. 1 Effect of climatic changes on emerging of infectious diseases

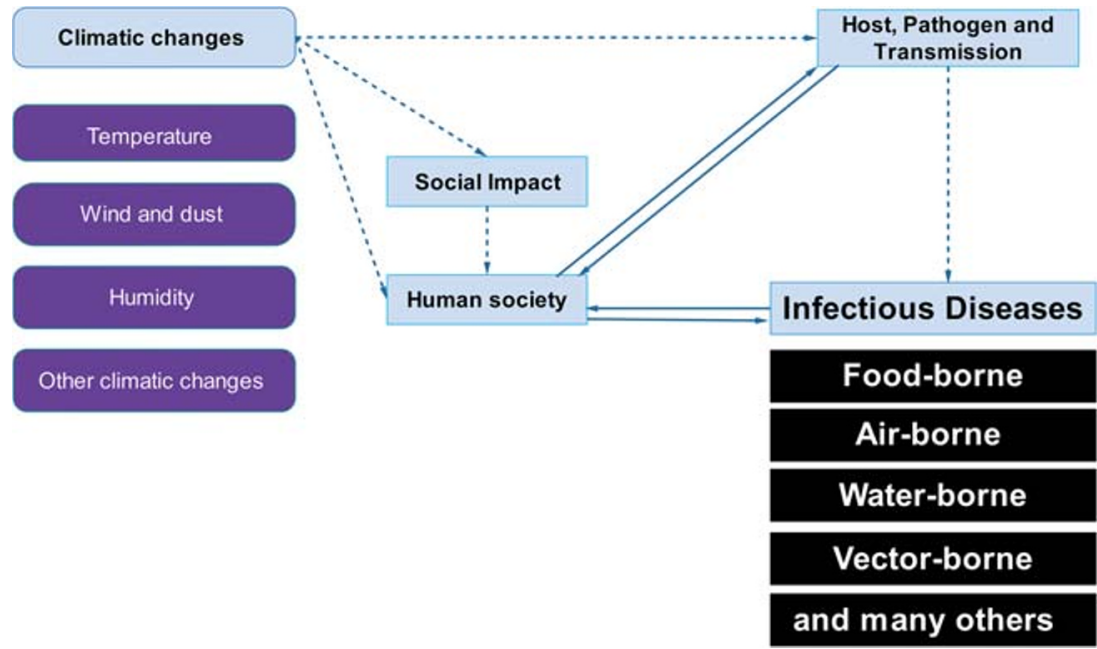


Fig. 2 Health hazard on human health due to climatic changes

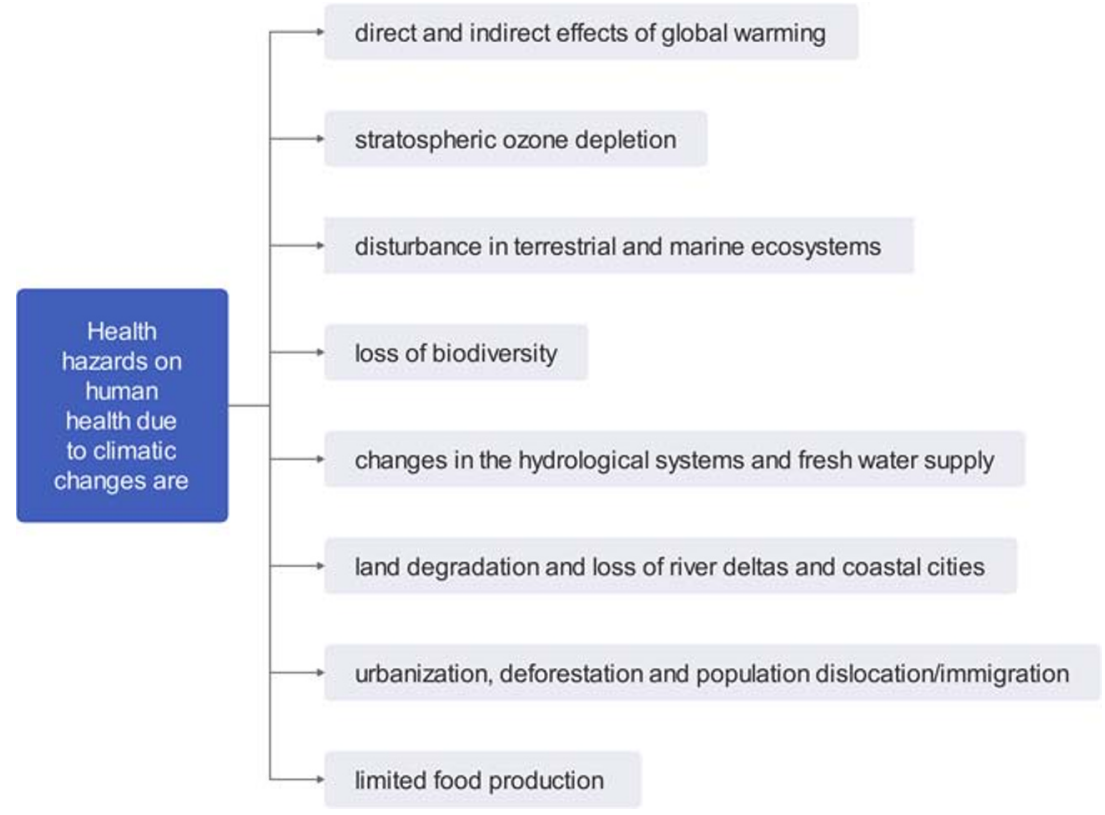

collapse, heat strokes, and the long-term effects include squamous-cell carcinoma. The direct effects also include the negative effects of floods, droughts and storms on the wildlife and forests. The global warming directly influences the abundance, survival, and distribution of pathogens and their vectors. Meanwhile, (2) the indirect effects include famines and the negative effects of massive migratory waves of human/ animal populations (Smith et al. 2017) and the resulting ecological shift is predicted-using an optimistic scenario- to induce at least 250,000 additional deaths annually between 2030 and 2050. Out of these, 48,000 are expected to die due to diarrhoea, 60,000 due to malaria and the rest due to malnutrition and heat strokes. Unfortunately, the poor developing countries are the most vulnerable countries although they are the least responsible for the $\mathrm{CO}_{2}$ emission and greenhouse effect (Dhimal et al. 2015a). It is alarming to know that more than $60 \%$ of human infectious diseases which emerged between 1940 and 2004 were zoonotic diseases of animal origin. This has a great impact on public health and world economy. Out of these, $22.8 \%$ are arthropod-borne diseases, and $71.8 \%$ originated from wildlife (Dantas-Torres 2015). It was unexpected that Nepal became endemic for many major vectorborne diseases (VBDs), although the land lies at high altitude due to Himalaya mountains. The diseases include malaria, leishmaniasis, filariasis, Japanese encephalitis and dengue fever (Dhimal et al. 2015a).

Emerging infectious diseases (EIDs) could be defined as infectious diseases which increase (their prevalence or threaten) over time. They include (1) new unknown diseases which are first diagnosed and (2) old diseases which evolved or mutated from already existing agents and gained new features (i.e. adaptation to new hosts or target population, new geographic distribution, new clinical picture, new epidemiological profile, new spread pattern or resistance to used therapeutics). The events that drive emerging of infectious diseases were illustrated in Fig. 3. Endemic diseases may also re-emerge where they are endemic (i.e. release epidemics or their prevalence increases clearly). Meanwhile, the reemerging diseases could be defined as new infections resulting from unknown or newly introduced pathogen to a new geographic area (Dikid et al. 2013; Epizooties OId 2014; Ogden and Gachon 2019). The major emerging and reemerging infectious agents in the last decade included Ebola virus (Africa), Middle East respiratory syndrome coronavirus (Middle East) and Zika, chikungunya, yellow fever and dengue viruses (North and South America) (Ogden and Gachon 2019). The CDC listed at least 50 emerging/re-emerging diseases worldwide. Some common examples of emerging and re-emerging diseases infecting human, animals or both were listed in Table 1. The list included Bovine spongiform encephalopathy, campylobacteriosis, Chagas disease, cholera, Cryptococcus, cryptosporidiosis, cyclosporiasis, cysticercosis, dengue fever, diphtheria, drug-resistant infections (antimicrobial resistance), Ebola haemorrhagic fever, Escherichia coli infection, group B streptococcus, hantavirus pulmonary syndrome, Hendra virus, hepatitis C, histoplasmosis, HIV/ AIDS, influenza, Lassa fever, Legionnaires' disease, leptospirosis, listeriosis, Lyme disease, malaria, Marburg haemorrhagic fever, measles, monkeypox, MRSA, Nipah virus, norovirus, pertussis, plague, poliomyelitis, rabies, Rift Valley fever, rotavirus, salmonellosis, severe acute respiratory syndrome, shigellosis, sleeping sickness (trypanosomiasis), smallpox, tuberculosis, tularemia, valley fever (coccidioidomycosis), vancomycin-intermediate or vancomycin-resistant, Staphylococcus aureus, West Nile virus and yellow fever which are mainly insect-borne, airborne, water-borne and 
Fig. 3 Events triggering the emergence of infectious diseases

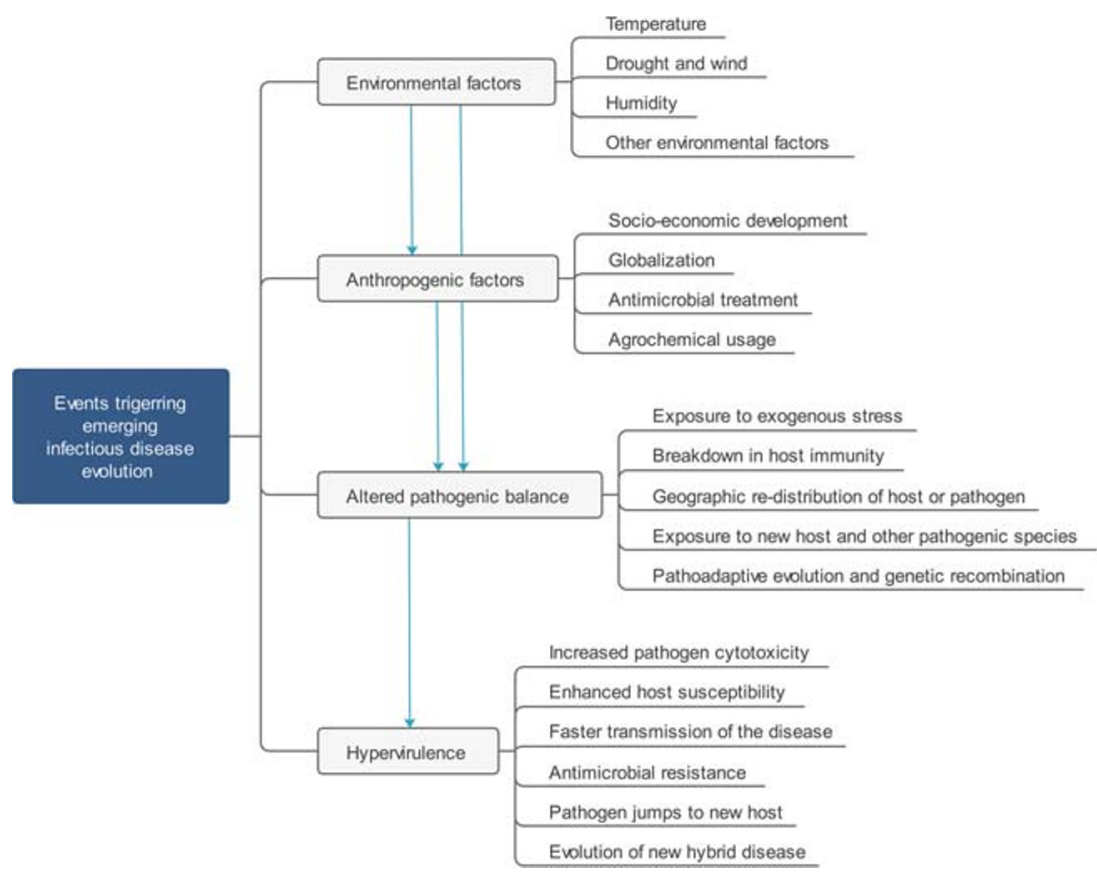

the wind intensity and direction, relative humidity and rainfalls in opposite to ticks. This is attributed to the life cycle of mosquitoes which depend on one stagnant water for laying eggs and for the development of larval stages. Reports concerning the increase in the prevalence of malaria due to climatic changes are already published in Iran (Babaie et al. 2018) and Zimbabwe (Gunda et al. 2017).

The invasion of new parasites and their emergence to free areas is also seen in the aquatic ecosystem. In Canada, parasitological investigations of the Laurentian Great Lakes basin determined at least 182 non-indigenous invading parasite species, i.e. a new invader species emerges every 28 weeks (Marcogliese 2008; Ricciardi 2006). The increase in seawater temperature-induced severe diseases to corals reefs which started to die. Coral reefs represent safe housing and food for several fish types. The increase in water temperature also leads to a decrease in the amounts of dissolved oxygen in the water. All these factors lead to great disturbance in the aqua ecosystem (Hakalahti et al. 2006; Harvell et al. 1999; Hayes et al. 2001).

\section{NTDs}

In the last years, the flow of refugees and illegal immigrants seeking asylum, coming from war/famine suffering countries increased the prevalence of many of the NTDs or their reemergence in western countries. One of the best examples is the human scabies caused by Sarcoptes scabiei mites. Although the parasitic disease has a global distribution, the prevalence in Europe was very low (Chandler and Fuller 2019). Outbreaks of scabies in Europe could be observed in 


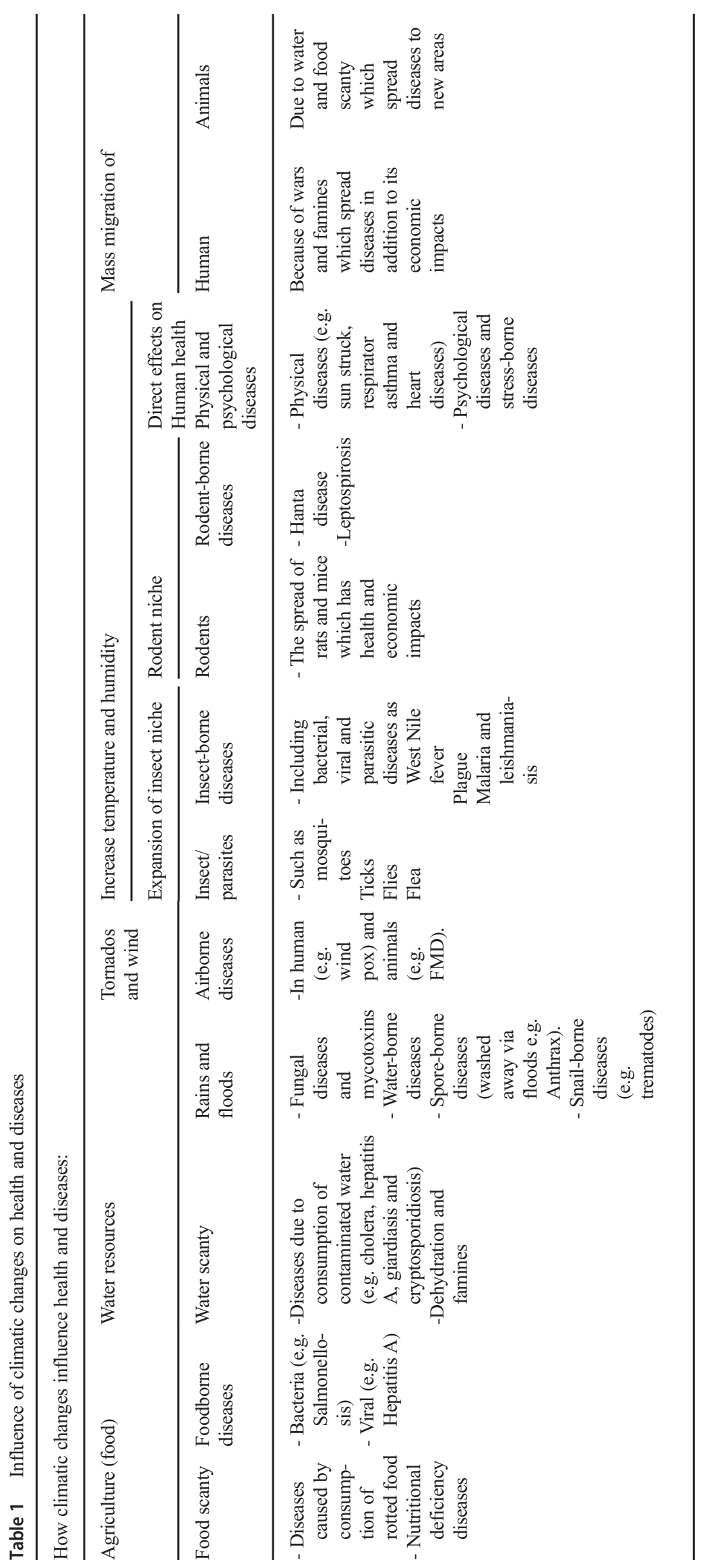


the last decade such as in Kindergarten in Germany in 2013 (Ariza et al. 2013) and in German Health Care Centre (Leistner et al. 2017) and in elderly home in the UK (Cassell et al. 2018). Other parasitic diseases are also involved in the NTD list, such as the following: (1) dracunculiosis (or guinea worm disease), dracunculiasis a parasitic water-borne disease caused by Dracunculus medinensis and occurs following drinking contaminated water (Biswas et al. 2013); (2) lymphatic filariasis (elephantiasis), a parasitic disease which obstructs the lymph vessels of the lower extremities and is transmitted by a wide range of mosquitoes, but the main vector is Anopheles and Culex quinquefasciatus (Control CfD, Prevention 2013); (3) onchocerciasis (or river blindness), a parasitic disease caused by the nematode Onchocerca volvulus and transmitted by blackflies (CDC 2017b); and (4) internal parasites including GIT nematodes and other trematodes such as Fasciola spp. and Schistosoma spp. They are very sensitive for climatic conditions which control their expansion pattern. For instance, floods, rainfalls, and the increased climatic temperature and humidity enable the survival of the free-living stages of the parasites (larva/metacercaria) and therefore increases disease prevalence. Schistosomiasis, Swimmer's itch or bilharzia are five species of trematodes belonging to the genus Schistosoma which require snails as intermediate hosts. The flocks invade the body through the skin (Mas-Coma et al. 2008) (CDC 2017a). The global warming expanded the habitat of the snail to a new land so that the disease is increasingly recorded in Europe (De Gentile et al. 1996; Kolarova 2007; Larsen et al. 2004). Recently, in 2015, an outbreak of urogenital schistosomiasis occurred in France. The victims were from France, Germany and Italy (Boissier et al. 2015). The snail vector of Schistosoma was also recorded in East Europe (Majoros et al. 2008; Pointier et al. 2005). Other snail mediated trematode parasites such as Fasciola, Clonorchis, Opisthorchis and Paragonimus also expand in a similar manner in association with the expansion of host to new geographical locations (Morgan et al. 2001). Fasciola hepatica is a zoonotic re-emerging neglected tropical parasite which infects mainly grazing sheep and cattle. The global warming increases the survival and expansion of the free-living cercaria and snail vector and at the same time, the increase of grazing season increases the exposure of the grazing animals to the parasite. Therefore and as expected, the prevalence of Fascioliasis increased in the last decade in endemic countries (Beesley et al. 2018).

Beside the previously mentioned parasitic diseases, NTDs of viral origin are also involved in the list, among them are as follows: (1) rabies, which is one of the most serious reemerging zoonotic NTDs - the free movement of wild animals represents a great obstacle in disease control (El-Sayed 2018; Hampson et al. 2015); (2) dengue fever, a serious viral disease which has four serotypes. The disease is transmitted by mosquitoes mainly Aedes aegypti and Ae. albopictus and is responsible for 96 million new infections yearly worldwide annual cases. Out of these, only 500,000 patients develop severe symptoms and 1250 fatalities (Dhar-Chowdhury et al. 2017). (3) Ebola haemorrhagic fever and the closely related Marburg fever. Both are fatal zoonotic viral diseases virus. Epidemiological studies linked outbreaks with climatic changes specially the rainfall/dryness seasonal patterns. Therefore, it is expected that global warming will affect the geographical distribution of both diseases (Schmidt et al. 2017).

Possibly one of the most serious emerging NTDs of bacterial origin is the leprosy. The disease is caused by mycobacterium lepra. Although leprosy was eradicated from Europe since hundreds of years, the NTDs emerged partially in some European countries recently. In Spain, between 2003 and 2013, a sum of 168 leprosy cases was registered. Out of them, 40 people were Spanish patients, while the remaining were illegal immigrants (Ramos et al. 2016).

\section{Foodborne and water-borne diseases}

Water-borne and foodborne diseases are a serious public health concern worldwide. Water-borne and foodborne outbreaks are closely associated with climatic changes and disturbances in the ecosystem. They are more common in the summertime and increase with rising temperatures and humidity (Greer et al. 2008). In addition, among the expected climate changes is the increase in frequencies of floods and heavy rainfalls due to warming of the oceans and due to the increase in frequency and strength of Al Nino and Hurricanes. This, in turn, will be reflected on the increase in water-borne diseases as giardiasis, cryptosporidiosis, infections with pathogenic E. coli, Shigella, cholera, Salmonella, and viral hepatitis A (Haines and Patz 2004). Consequently, floods and the increase in water volume will lead to the overload of sewage drainage systems and their overflow and contamination of drinking water. The increase in global temperature will also enhance the emergence of freshwater snails to free areas which enable the expansion of snail mediated trematodes (McCarthy et al. 2001; Portier et al. 2017). Therefore, global warming will result in a significant and serious increase in the worldwide prevalence of enteric/diarrhoeal diseases, but it can even induce fatal epidemics such as epidemics caused by fatal thermophilic free-living amoeba the Naegleria fowleri which induce fatal meningoencephalitis (Huizinga and McLaughlin 1990; Sykora et al. 1983). In the USA, the emergence of most water-borne outbreaks was associated with severe precipitation (Rose et al. 2001).

The most famous water-borne disease is the cholera, a bacterial diarrheal disease caused by Vibrio cholerae. The disease is transmitted by drinking contaminated water. Cholera is a highly temperature-dependent disease which increases with the increase in water temperature. Infection due to Vibrio 
spp. is an example of the influence of global warming and ecology on the emergence of pathogens. The increase in water temperature affects the plankton population in water. The symbiotic relationship between vibrio and plankton leads to the increase in abundance of vibrio population. Swimmers who have open wounds and shellfish consumers can easily attract the infection. Similarly, Vibrio cholera is associated with zooplankton and both V. cholera and zooplankton population will bloom when the water temperature increases (Redshaw et al. 2013). The prevalence of Vibrio associated diseases increased clearly worldwide in the last decades and could even emerge in many Northern European countries as a response to global warming (Pascual et al. 2000; Semenza et al. 2012). The infections spread in warm summers via swimming pools and in coastal cities (Andersson and Ekdahl 2006; Baker-Austin et al. 2013; Frank et al. 2006; Schets et al. 2006). The spread of water-borne epidemics as leptospirosis and gastrointestinal infections is usually associated with heavy rainfall and floods (Cann et al. 2013).

The increase in temperature will selectively adapt fungi to higher environmental temperatures which resample that of mammals. So that pathogenic fungi, which are at the time not pathogenic for mammals due to their body temperature, will be capable of infecting mammals in the future (GarciaSolache and Casadevall 2010). Climatic factors can also promote the spread of non-infectious diseases (e.g. the increase in humidity, temperature and rainfalls enhance the growth of fungi and the spread of mycotoxin related diseases). In warm summer, many factors interact leading to the increase in cases of food poisoning such as enhanced bacterial survival, the people spend more time outside where they eat and drink, and finally due to the increase in the insect/rodent population and activity (El-Sayed et al. 2008; Milazzo et al. 2017; Park et al. 2018; Touchon et al. 2009).

\section{Insects and insect-borne diseases}

Global warming influences both vector host dimensions in a way which controls their spatiotemporal expansion and the emergence of the diseases in a complex but balanced way (Morgan et al. 2001; Renn et al. 2011). Vector-borne pathogens are usually geographically restricted to certain areas where their vectors exist. However, the emergence of the transmitting vectors to new districts as a result of global warming is logically associated with the emergence of these vector-borne pathogens (Cann et al. 2013). In the last years, several diseases could emerge in Europe in relation to their vector expansion such as dengue fever, West Nile fever, chikungunya fever, malaria, leishmaniasis, Lyme disease and tick-borne encephalitis (Baylis 2017).

The emerging of new infectious diseases due to the geographical expansion of the insect vector should not be underestimated. One vector (e.g. Aedes albopictus) can alone transmit at least 22 different types of arboviruses in addition to various parasitic diseases such as dengue fever, yellow fever, West Nile virus, Eastern equine encephalitis, chikungunya virus, Ross River virus, Usutu virus, and the nematodes Dirofilaria immitis and D. repens (Redshaw et al. 2013).

The northern expansion of vectors like ticks and mosquitoes lead to the emergence of VBDs in North America and Scandinavian. The tick-borne diseases include diseases like babesiosis, anaplasmoses, and Powassan encephalitis, while the mosquito-borne diseases involve diseases like dengue fever and malaria. Other victors like sandflies introduced diseases like Lyme disease, Boutonneuse fever and leishmaniasis. Similarly, the southern expansion of victors in Australia increased the prevalence of insect-borne diseases according to health records such as Ross River virus, Murray Valley encephalitis and Barmah Forest virus (Greer et al. 2008).

\section{Mosquito}

While the increase in temperature enables the survival of mosquitoes and the elongation of their season of activity, heavy rainfalls are also necessary to provide standing water surface required for egg-laying and larval development. High levels of air humidity enhance the vector population dynamics. Finally, the wind plays an important role in the spread of mosquitoes and their associated diseases. The wind was incriminated to be the reason for the emergence of Culex tritaeniorhynchus mosquitoes in several areas in China (Min and Xue 1996; Walsh et al. 2008).

Three genera of mosquitoes (Aedes, Culex and Anopheles) are the mostly incriminated in transmission of diseases to men and animals. The mosquito-borne diseases may expand either through the emergence of the victor species to a new area or through the adaptation of the introduced mosquito-borne pathogen to native mosquito species which already exist in this location. The best example for that is the chikungunya virus which is usually transmitted by Aedes albopictus. Following its emergence in Europe, the native European mosquito species such as Ae. geniculate were found to be highly susceptible to chikungunya virus infection and can replace Aedes albopictus in disease epidemiology ( $\mathrm{Ng}$ et al. 2019; Prudhomme et al. 2019). The best example for the second possibility is seen by Aedes aegypti which is endemic in Africa. The exotic mosquito species emerged in the Netherlands but could not persist due to the unsuitable environmental conditions. In opposite to the case in Portugal where the invader species could establish itself in 2002 and induced dengue fever outbreak a few years later in 2012 (Scholte et al. 2010; Sousa et al. 2012). Similarly, invasive Aedes species could be routinely detected between the years 2016 and 2018 in different localities in Canada (June 2018). 
However, beside the effects of environmental changes which favour the increase in insect population, human activities may also induce changes in mosquito population as was seen in Belgium. The intensive rearing of pigs and the collection of manure nearby enabled the shift in larval habitat from tree holes in forests to the pig farm manure (Dekoninck et al. 2011). At the time, at least 8 human pathogenic insect-borne viruses from the families are circulating in European populations, namely, sindbis and chikungunya (Togaviridae), Batai, Tayna, snowshoe hare and Inkoo (Bunyaviridae) and finally West Nile, Usutu, and dengue (Flaviviridae) (Vazquez et al. 2011).

When we investigate the mosquito-borne diseases such as dengue fever, yellow fever, and chikungunya virus (transmitted by Aedes species), West Nile fever, Eastern equine encephalitis and heartworm infection (by several mosquito species including Anopheles, Aedes, Culex, Culiseta, Coquillettidia, Deinocerites, Mansonia, Orthopodomyia, Psorophora and Uranotaenia), Ross River fever and Usutu virus infection (by Culex and Aedes) and malaria (by Anopheles and Aedes) (Redshaw et al. 2013), we would notice that one mosquito species (Aedes aegypti) out of 3500 mosquito species is responsible for most serious outbreaks and can transmit most of the mosquito-borne pathogens outside Africa (Powell 2018). While Aedes aegypti is common in Africa, another species which originates from Asia (tiger mosquito Aedes albopictus) emerged in Europe and North America and was considered as the most invasive mosquito species and one of top 100 invasive insect species worldwide. Tiger mosquitoes are known for being very aggressive diurnalbiting insects. It can transmit more than 20 pathogens to humans alone (Ogden et al. 2014). Tiger mosquitoes are responsible for the emergence of several diseases to Europe such as chikungunya fever (Italy in 2007 and France in 2010) (Fischer et al. 2013). The emergence and expansion of A. albopictus in the Western Hemisphere enhanced the emergence and endemicity of $A$. albopictus-borne diseases like chikungunya virus infection and dengue fever in Italy, France and Croatia in Europe, and in Hawaii, Texas and Florida in USA. West Nile virus became now also endemic in North America after its emergence due to migratory birds (Redshaw et al. 2013).

According to the published data, three major emerging mosquito-borne viruses represent a global challenge for public health: (1) West Nile virus (WNV), an insect-borne virus which induces fatal encephalitis in mammals, humans and even birds. The virus is transmitted by Culex mosquitoes. Like other mosquito-borne diseases, the disease expanded its geographic range to emerge in new countries as a result of climatic changes. The disease emerged in South America in 2003 and induced a large outbreak in Europe in 2010 (involved Greece, Romania, Hungary, Spain, Russia, Turkey and Italy) (Paz 2015). The disease was also detected in other
European countries such as France, Portugal and Serbia. The source of the invading viruses was confirmed to be from Israel, Morocco and Turkey. Later on, in 2018, the virus emerged for the first time in Germany (Ziegler et al. 2019). In 1999, WNV first emerged in New York (USA), the increase in mosquito population due to the increase rainfalls and the lengthening of the mosquito activity season due to the increase in temperature leads to the increase of the prevalence of the disease. In 2013, 2170 cases of WNF were reported in USA with 88 fatalities (Kilpatrick et al. 2006; Paz 2015). (2) Chikungunya virus is transmitted by Aedes mosquitoes. In the last decade, Ae. Albopictus spread in Europe, North and South America, and many countries in Africa; this resulted in the recent emergence of the chikungunya virus to more than 40 countries worldwide (Sanyaolu et al. 2016). The increase in temperature was found to be linearly related to the increase in disease prevalence (Dhimal et al. 2015b). The epidemiological map of the diseases indicated its confirmed existence in at least in 98 countries ( 24 in Africa, 20 in Asia, 44 in North and South America, 10 countries in Pacific Islands) (Sanyaolu et al. 2016). Additionally, the virus emerged in 2007 for the first time in Europe (Italy) where it infected at least 200 persons (Rezza et al. 2007). Later on, in 2010, the highly aggressive Asian tiger mosquito (Ae. Albopictus) spread both chikungunya and dengue viruses to France and Croatia, and in 2012 to Portugal (Sousa et al. 2012). However, a part of this ability to widespread is attributed to its genetic mutation which enabled the virus to use Asian tiger mosquito as a vector and not being restricted to yellow fever mosquito alone (CE TKVDM 2007). (3) Zika virus which induced serious public health problems in South America between 2015 and 2016 is expected to emerge in Europe as both of its vectors $A e$. aegypti and Ae. albopictus are endemic in Europe (Caminade et al. 2017).

Other mosquito-borne viruses are also investigated. Repeated horse outbreaks with the mosquito-borne Eastern equine encephalitis virus could be detected in Ontario in 2008, 2009 and 2010. The virus reported its first human infection in 2016 (Chénier et al. 2010; Ludwig et al. 2019). Other mosquito-borne viruses include the following: (1) Usutu virus (flavivirus) was isolated for the first time from human patients in Italy in 2009 and from migrating birds in Germany in 2011 (Vazquez et al. 2011). At the time, the viruses seem to be circulating in several European countries (Gaibani and Rossini 2017). (2) Rift Valley fever virus (Bunyaviridae: Phlebovirus) is a serious emerging zoonotic disease in Africa and the Middle East. The disease has a great economic impact and represents a public health concern. Like other emerging insect-borne diseases, the global warming supports their geographical expansion. The virus was introduced to Europe in 2016 through a French service member in Mali who caught the infection in Mali before travelling to France via Crete, Greece. Fortunately, the disease did not persist there 
(Tong et al. 2019). (3) Yellow fever is a tropical viral disease which started to induce outbreaks in South America (in particular in Brazil and Argentina). Although North America and Europe are free of the virus, the virus emerged in both continents in the past (seventeenth and nineteenth centuries) according to WHO. In the last decades, the virus started to invade new countries in association with mosquito active seasons (Report W 2015), and finally, the bluetongue virus emerged in 2006-2007 across 12 European countries in northern Europe and UK. The wind is believed to be responsible for the disease introduction to Europe by spreading the vector (Cu. imicola) northward. Beside the main vector $(C u$. imicola), additional native European species ( $\mathrm{Cu}$. obsoletus, $\mathrm{Cu}$. pulicaris, $\mathrm{Cu}$. chiopterus and $\mathrm{Cu}$. dewulfi) shared in the spread of the virus across Europe (Gould and Higgs 2009; Molyneux 2009; Purse et al. 2005) (Table 2).

Mosquito is also capable of transmitting parasitic diseases such as malaria and filariasis. Malaria is the most serious and fatal parasitic disease worldwide with more than 214 million annual clinical cases and half a million deaths, $90 \%$ of which live in Africa. These numbers are expected to expand in response to global warming. The situation is additionally complicated due to the growing resistance against antiplasmodium drugs and by mosquitoes against insecticides (Gunda et al. 2017; Ssempiira et al. 2018). Historically,

Table 2 Some common examples of emerging and re-emerging diseases infecting human, animals or both

\begin{tabular}{|c|c|c|c|}
\hline & Bacterial diseases & Viral diseases & $\begin{array}{l}\text { Parasitic } \\
\text { diseases }\end{array}$ \\
\hline Human & $\begin{array}{l}\text { - Tuberculosis } \\
\text { - Hemorrhagic colitis } \\
\text { (HC) and } \\
\text { haemolytic uremic } \\
\text { syndrome (HUS) } \\
\text { caused by Shiga } \\
\text { Toxin producing } \\
\text { E. coli (STEC) }\end{array}$ & $\begin{array}{l}\text { - } \text { Coronavirus } \\
\text { disease } 19 \\
\text { (COVID-19) } \\
\text { - Middle East } \\
\text { respiratory } \\
\text { syndrome } \\
\text { coronavirus } \\
\text { (MERS) } \\
\text { - Severe acute } \\
\text { respiratory } \\
\text { syndrome } \\
\text { coronavirus } \\
\text { (SARS) } \\
\text { - Ebola virus } \\
\text { infection }\end{array}$ & $\begin{array}{l}\text { - Malaria } \\
\text { Schistosomia- } \\
\text { sis }\end{array}$ \\
\hline Animal & $\begin{array}{l}\text { - Swine edema (by } \\
\text { Stx2e producing } \\
\text { E. coli) } \\
\text { - Bartonella henselae } \\
\text { - Pasteurella } \\
\quad \text { multocida } \\
\text { infections }\end{array}$ & $\begin{array}{l}\text { - Swine acute } \\
\text { diarrhoea } \\
\text { syndrome } \\
\text { coronavirus } \\
\text { (SADS-CoV) }\end{array}$ & $\begin{array}{l}\text { - Fasciola } \\
\text { Trypanosomi- } \\
\text { asis }\end{array}$ \\
\hline Zoonotic & $\begin{array}{l}\text { - Methicillin-resistant } \\
\text { Staphylococcus } \\
\text { aureus (MERSA) } \\
\text { - Leptospirosis }\end{array}$ & $\begin{array}{l}\text { - West Nile fever } \\
\text { - Rabies } \\
\text { - Avian influenza }\end{array}$ & $\begin{array}{l}\text { - Leishmaniasis } \\
\text { - Ascariasis }\end{array}$ \\
\hline
\end{tabular}

malaria invaded Europe on many occasions. Old reports from ancient Roma reported the presence of Malaria in Italy thousands of years ago (Micallef 2016; Sallares 2002). Newer reports from the year 1265 reported the presence of malaria in Croatia; seventeenth century documented the reintroduction of malaria to Europe through Spain. However, in the twentieth century, WHO launched a global malaria eradication program which resulted in the eradication of malaria from 79 countries worldwide (mainly in Eurasia, Australia, northern America, and northern Africa with the exception of Turkey and countries of middle Asia including Azerbaijan, Georgia, Kyrgyzstan and Tajikistan) (Askling et al. 2012; Caminade et al. 2014). The eradication of malaria from Europe was officially declared in 1975 and was achieved via the drainage of wetland and stagnant water, chemical treatment of patients, biological control of the mosquito larvae using the fish Gambusia holbrooki, improvement of water system and sewage infrastructure (Talapko et al. 2019). However, recently, between 2009 and 2012, several cases were diagnosed in Greece (Danis et al. 2011). Later on, malaria was re-introduced in Croatia, Italy, Malta, Bulgaria, France, Germany and Spain (Krüger et al. 2001; MedialdeaCarrera et al. 2018; Monge-Maillo and López-Vélez 2012). In Greece, in 2011, Plasmodium vivax could be isolated from the blood of 40 patients from different regions of the country. The patients were infected locally as they have no travelling history to the outside (Ivanescu et al. 2016). In the same year, in Romania, malaria was also diagnosed but fortunately, the disease was imported with travellers from Italy (Neghina et al. 2011; Nicolescu et al. 2016). However, and although most countries in Europe are malaria-free since decades, the Anopheles vector continued to live and exist there. The persistence of the vector represents a great threat for the reemerge of the diseases any time, and it is expected to reemerge in the rest of Europe and USA as the climatic changes favour the re-emergence of the disease (Askling et al. 2012). These speculations are supported by computer modelling programs which predict the re-emergence of malaria in Europe and USA in the near future (Kuhn et al. 2003). On the other hand, in the already endemic countries such as Iran and Zimbabwe, the prevalence of malaria increased in the last few years as reported (Babaie et al. 2018; Gunda et al. 2017).

The development of malaria inducing Plasmodium vivax and $P$. falciparum is highly influenced by environmental temperature. The global warming is expected to result in a $12-27 \%$ increase in disease prevalence and therefore threaten the life of an additional 200 million persons (Redshaw et al. 2013).

\section{Tick-borne diseases}

The association between global warming and the emergence of tick-borne diseases is well documented in Europe and 
Euroasia (Andreassen et al. 2012; Daniel et al. 2003; Gilbert 2010; Jore et al. 2011; Lindgren 2000; Tokarevich et al. 2011). These data were also confirmed by long-term studies over 30 years of tick expansion observation in Sweden (Jaenson et al. 2012). Like mosquitoes, several tick species expanded their habitat to higher elevations and toward the north in Canada and Europe due to global warming which elongated the season of tick activity and enhanced their survival in the environment. This, in turn, was also reflected on the spread of tick-borne diseases such as Anaplasmosis, Babesiosis Powassan viruses and Rickettsia Helvetica, Neoehrlichia mikurensis and Borrelia miyamotoi diseases (Bouchard et al. 2019; Jado et al. 2007; Kawahara et al. 2004).

Although ticks can transmit the most diverse array of pathogens than all other arthropod vectors, fortunately, the tickborne diseases emerge usually much slower than mosquitoborne diseases (Wikel 2018). Ticks alone were found to transmit at least $95 \%$ of known insect-borne diseases in the USA (Adams et al. 2015).

The expansion of Ixodes ricinus ticks (victor of Borrelia burgdorferi spirochetes) poleward in Europe and Eurasia is well documented. The tick could be detected in UK, Germany, Sweden and Russia (Cull et al. 2018; Jaenson et al. 2012; Mannelli et al. 2012). The expansion of another tick species in Europe and Eurasia was also reported (Dermacentor reticulatus) which is the vector of tick-borne encephalitis virus, Omsk haemorrhagic fever virus, Rickettsia slovaca, Rickettsia raoultii, Anaplasma marginale, Babesia canis, Babesia caballi and Theileria equi (Altizer et al. 2013; Földvári et al. 2016). Similar reports documented the extension of the habitat of the tick species Ixodes scapularis (transmit Lyme borreliosis), Amblyomma americanum (vector of Amblyomma americanum transmitted Ehrlichia chaffeensis and Ehrlichia ewingii) and Amblyomma maculatum (transmit Rickettsia parkeri, potted fever agent, and the canine apicomplexian (Hepatozoon americanum)) and Hemaphysalis longicornis to involve new land in North America (Eisen and Eisen 2018; Ogden and Lindsay 2016; Paddock and Goddard 2015; Sonenshine 2018). Human cases of tick-borne babesiosis were recently reported in Canada, Europe and Japan (Kulkarni et al. 2015; Vannier and Krause 2012, 2020).

Tick expansion is promoted by the warmer winters in the last decade due to global warming (Porretta et al. 2013; Tokarevich et al. 2011). In the last few years, more than 11 bacterial tick-borne human emerged pathogens were detected in Europe which include various Rickettsiae and Borrelia species (Parola and Raoult 2001). Ticks transmitted by migrating birds also play an epidemiological role in the spread of the pathogens. In one study, 16 out of 43 migrating bird species were infested with at least one tick. The ticks were positive for $C$. burnetii, Rickettsia spp. and $R$. helvetica in addition to Babesia microti, B. capreoli and B. venatorum in variable degrees (Lu et al. 2016). Beside the birds, the epidemiological role of ticks in the transmission of zoonotic bacteria Coxiella burnetii was recently confirmed (Berthová et al. 2016; Koehler et al. 2019; Pacheco et al. 2013).

Recent reports listed the main tick-borne pathogens endemic in Europe, such as Rickettsia, A. phagocytophilum, Borrelia burgdorferi, Babesia spp., Borrelia miyamatoi, Bartonella henselae, Candidatus N. mikurensis, Francisella tularensis and the viruses Crimean-Congo haemorrhagic fever virus (CCHFV) and the tick-borne encephalitis (TBEV). The prevalence and their geographical distribution are expanding (Amicizia et al. 2013; Hartemink and Takken 2016; Jaenson et al. 2012). In addition, ticks are also capable of transmitting a large number of serious zoonotic viruses. The spread of the resulting diseases is coupled with the geographical expansion of ticks and their emergence in new areas (Kazimírová et al. 2017; Tokarz et al. 2014, 2018). The list of the transmitted viruses includes Phlebovirus (induces thrombocytopenia and high fever) (Fatmi et al. 2017; Holbrook 2012; McMullan et al. 2012), Bourbon virus, Powassan virus, tick-borne encephalitis viruses complex, CCHFV and Alkhurma haemorrhagic fever virus (Mansfield et al. 2009).

Tick-borne encephalitis (TBE) and Lyme disease emerged in Europe in connection to tick expansion. Cases of both diseases were even reported in Scandinavia. The disease prevalence is increasing in an alarming way due to global warming and northwards emergence of tick vector (Lindgren 2000; Lukan et al. 2010; Randolph 2004). Since the mid-1980s, the winter in Scandinavian got warmer. Since then, the prevalence of TBE increases steadily and clearly. Many factors are believed to be the actual reasons for this increase, mainly the climatic changes (Andreassen et al. 2012; Lindgren and Gustafson 2001). One of the TBE complex viruses is the Louping ill virus. The disease was also recently detected in Europe and UK (Gilbert 2016).

A second zoonotic tick-borne emerging viral diseases in Europe is the Congo haemorrhagic fever (CCHF). The $\mathrm{CCHFV}$ represents a great public health concern in Europe due to its high human fatality (Papa et al. 2015). The virus is transmitted by Hyalomma tick to ruminants, and now it became endemic in Africa, the Middle East, the Balkan Peninsula, Eastern and South Europe and Asia. Warmer climatic conditions allow the ticks to invade and emerge in new areas (Baylis 2017). Additionally, ticks are responsible for the emergence of Piroplasmorida (such as Babesia and Theileria). Babesiosis is the most important tick-borne protozoal disease to cattle industry. The disease is a global animal health problem responsible for great economic losses in the veterinary sector. The emerging zoonosis represents a great challenge of public health due to the exponential increase of babesiosis worldwide facilitated by the geographic expansion of ticks induced by global warming (Beugnet and Chalvet-Monfray 2013, Florin). At the time, there are more than 100 known 
babesia species, half of them are recently discovered (Florin). Many of them have zoonotic importance such as B. microti, B. microti-like organisms, $B$. duncani, $B$. duncani-like organisms, $B$. divergens, $B$. divergens-like organisms and B. venatorum (Vannier and Krause 2020).

Beside Babesia, the Anaplasma and Ehrlichia are also important tick-borne pathogens of zoonotic importance (Brown and Barbet 2016). The tick-borne disease caused by Anaplasma phagocytophilum is a serious zoonotic disease which infects humans, cattle, equines and canines. The disease can be transmitted by different tick species endemic in Europe (e.g. Ixodes ricinus), North America (e.g. Ixodes scapularis, Ixodes pacificus and Ixodes spinipalpis) and Asia (e.g. Ixodes persulcatus) (Stuen et al. 2013).

Beside Anaplasma, the closely related tick-borne Ehrlichia can also infect human and animals. The diseases can be induced by Ehrlichia chaffeensis and Ehrlichia ewingii (Monocytes Ehrlichiosis) in human or heartwater in cattle (by Ehrlichia ruminantium) (Allsopp 2015; Paddock and Childs 2003; Thomas et al. 2009). Other forms of ehrlichiosis can also be induced by other Ehrlichia species like Ehrlichia canis, Ehrlichia muris and Ehrlichia mineirensis. As a tickborne pathogen, Ehrlichia species could be detected almost worldwide (Allsopp 2015).

The northward expansion of the dog tick Rhipicephalus sanguineus is alarming due to their role in the emergence of the life-threatening pathogens such as Rickettsia rickettsii and $R$. conorii, the causative agents of Rocky Mountain spotted fever and Mediterranean spotted fever, respectively (Parola et al. 2008). The related tick-borne Rickettsia and Borrelia species usually emerge parallel to Anaplasma and Ehrlichia as they are also transmitted by a large variety of tick species. The emergence of Borrelia bacteria in addition to TBE virus resulted in huge concern in Europe (Gage et al. 2008).

The ticks can also transmit various bacterial diseases such as Lyme borreliosis. In the last decade, the prevalence of the disease in Europe increased not only in endemic areas but also expanded to new geographical regions, particularly in Netherlands and Belgium. It is estimated that Lyme borreliosis (bacterial spirochaete disease) infects yearly at least 85,000 people in Europe (Gassner and van Overbeek 2007; Hofhuis et al. 2015). The disease is caused mainly by Borrelia burgdorferi and Borrelia mayonii in Europe. However, other species of Borrelia like Borrelia spielmanii, Borrelia bavariensis, Borrelia afzelii and Borellia garinii were also reported in North America and Euroasia as potent zoonotic spirochetes transmitted by Ixodes ricinus complex (Kernif et al. 2016; Merhej et al. 2014; Parola et al. 2005; Rizzoli et al. 2011). In addition ticks, fleas and flies can aid in the expansion of rabbit fever (tularemia), a zoonotic vector-borne disease caused by Francisella tularensis (Nakazawa et al. 2007).
Mosquitoes and ticks are not the only insect vectors affected by global warming. Additional parasites like fleas, triatomine bugs and bloodsucking flies such as sandfly (Phlebotomus and Lutzomyia spp.), Glossina tsetse flies, horsefly (Tabanus spp.) and deerfly (Chrysops sp.) were also incriminated in the introduction of emerging diseases to new locations such as tularemia, Yersinia pests, Leishmaniasis and Trypanosoma in response to climatic changes (Bern et al. 2007; Hargrove 2004; Nakazawa et al. 2007; Redshaw et al. 2013).

Sandflies (Phlebotomus species) can transmit leishmaniasis (cutaneous and visceral forms). The diseases emerged in South Europe, UK and Germany and infected humans and dogs there (Dujardin et al. 2008). More than $90 \%$ of the human cases live in India, Bangladesh, Sudan, South Sudan, Ethiopia or Brazil (Mitra and Mawson 2017). However, Phlebotomus spp. were recorded in Switzerland, Germany, Austria, Spain, Portugal, France, Italy, Belgium, Greece, Malta, Cyprus, Andorra and Corsica (Aransay et al. 2004; Ballart et al. 2012; Dereure et al. 2009; ECDC 2013). The sandfly expansion reached later East European countries like Bulgaria, Croatia, Albania, Bosnia and Herzegovina, Croatia, Georgia, Hungary, Montenegro, Romania, Serbia, Macedonia, Turkey and Ukraine (ECDC 2013). The detection of sandfly was associated with the expansion of the leishmaniasis mainly in dogs (Boecken et al. 2011; Ready 2010). This expansion was attributed to global warming (Gálvez et al. 2011).

African trypanosomiasis (sleeping sickness) is a protozoal disease transmitted by tsetse flies and caused by Trypanosoma brucei gambiense and T. brucei rhodesiense. Due to the vector expansion in relationship with the global warming, it is predicted that 30,000 people will be infected by the parasite while 70 million persons will be at risk during this century (Moore et al. 2012). Another type of trypanosomiasis started to emerge from Latin America, namely Chagas disease caused by Trypanosoma cruzi and transmitted by the bites of the bloodsucking Triatoma infestans known as the kissing bugs or orally by the consumption of water or food contaminated with the faeces of the infected bugs. The disease expansion to Central and North America was reported. At the time, it is estimated that 300,000 US residents are infected with the disease (Shikanai-Yasuda and Carvalho 2012).

The flea Xenopsylla cheopis is the vector of Yersinia pestis, the causative agent of plague. Warmer and wetter conditions are benefiting both the flea vector and Yersinia pestis (Nakazawa et al. 2007) (Ben Ari et al. 2008).

\section{Rodents and rodent-related diseases}

Rodents play an important role in the epidemiology of disease emergence/re-emergence. They are capable of transmitting a 


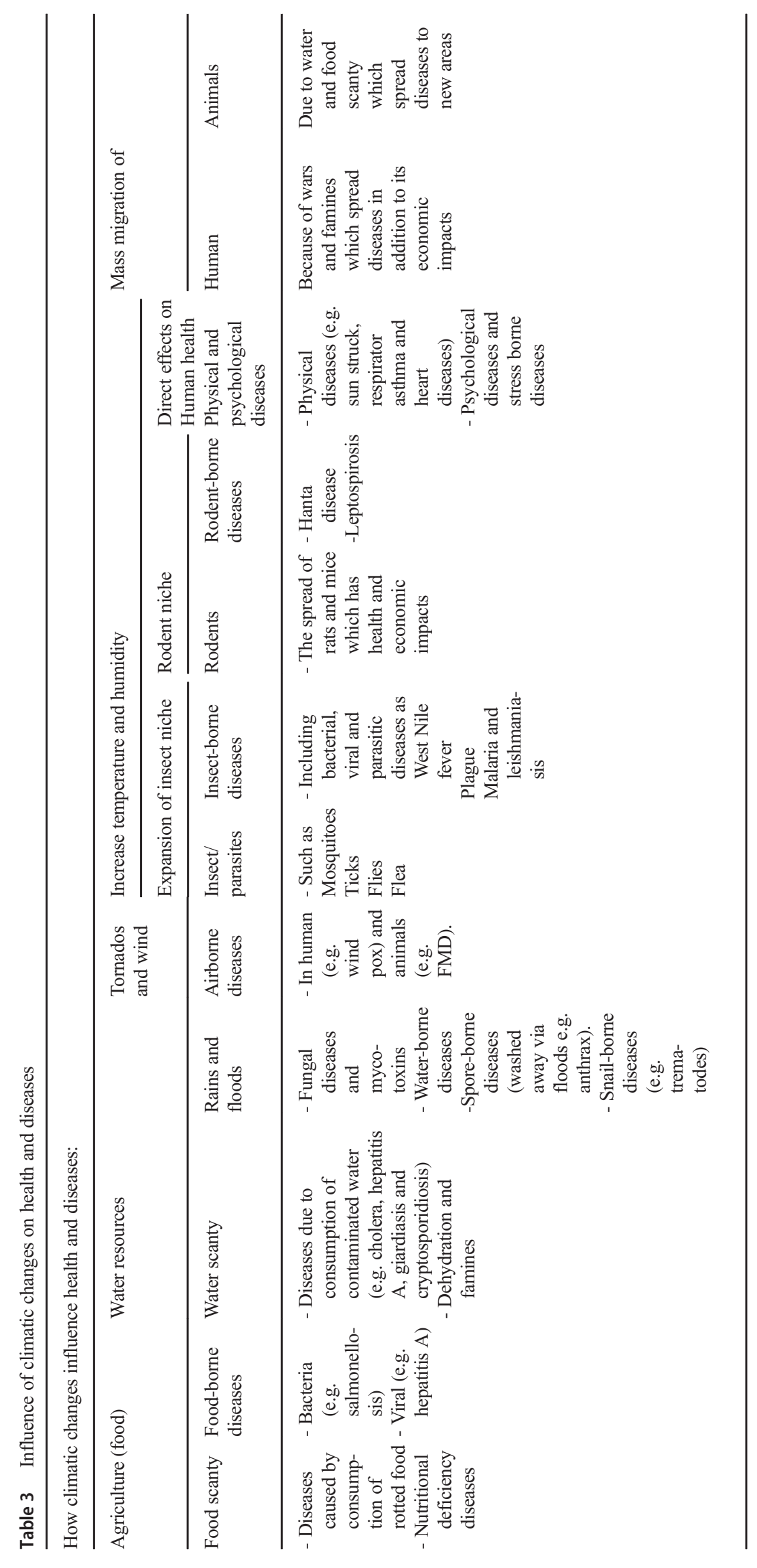


large number of zoonotic disease agents either directly such as leptospirosis, Sin Nombre virus and Hantaan virus which spread via dust contaminated with dried rodent urine (Hansen et al. 2015) (Pijnacker et al. 2016) or indirectly as plague (Yersinia pestis). The global warming influences the change in rodent distribution maps and their population worldwide (Moore et al. 2011).

In conclusion, it is necessary to make all possible efforts to stop or at least to slow down the accelerated damage of the global ecosystem due to global warming and climate changes. The disturbance in the balanced ecosystems will not only lead to the emergence of infectious diseases but also has long-term serious direct and indirect damaging effects which threaten the existence of human, animals and plants (Table 3 ).

\section{Compliance with ethical standards}

Conflict of interest The authors declare that they have no conflict of interest.

\section{References}

Adams DA, Fullerton KE, Jajosky RA, Sharp P, Onweh DH, Schley AW, Anderson WJ, Faulkner A, Kugeler KJ (2015) Summary of notifiable infectious diseases and conditions-United States, 2013

Allsopp BA (2015) Heartwater-Ehrlichia ruminantium infection

Altizer S, Ostfeld RS, Johnson PT, Kutz S, Harvell CD (2013) Climate change and infectious diseases: from evidence to a predictive framework. Science 341:514-519

Amicizia D, Domnich A, Panatto D, Lai PL, Cristina ML, Avio U, Gasparini R (2013) Epidemiology of tick-borne encephalitis (TBE) in Europe and its prevention by available vaccines. Human Vaccines \& Immunotherapeutics 9:1163-1171

Andersson Y, Ekdahl K (2006) Wound infections due to Vibrio cholerae in Sweden after swimming in the Baltic Sea, summer 2006. Euro Surveill 11:E060803

Andreassen A, Jore S, Cuber P, Dudman S, Tengs T, Isaksen K, Hygen HO, Viljugrein H, Ånestad G, Ottesen P (2012) Prevalence of tick borne encephalitis virus in tick nymphs in relation to climatic factors on the southern coast of Norway. Parasit Vectors 5:177

Antonenko YN, Khailova LS, Knorre DA, Markova OV, Rokitskaya TI, Ilyasova TM, Severina II, Kotova EA, Karavaeva YE, Prikhodko AS (2013) Penetrating cations enhance uncoupling activity of anionic protonophores in mitochondria. PLoS One 8:e61902

Aransay AM, Testa JM, Morillas-Marquez F, Lucientes J, Ready PD (2004) Distribution of sandfly species in relation to canine leishmaniasis from the Ebro Valley to Valencia, northeastern Spain. Parasitol Res 94:416-420

Ariza L, Walter B, Worth C, Brockmann S, Weber M-L, Feldmeier H (2013) Investigation of a scabies outbreak in a kindergarten in Constance, Germany. Eur J Clin Microbiol Infect Dis 32:373-380

Askling H, Bruneel F, Burchard G, Castelli F, Chiodini P, Grobush M, Lopez-Velez R, Paul M, Petersen E, Popescu C (2012) On behalf of the European Society for Clinical Microbiology and Infectious Diseases Study Group on Clinical Parasitology: management of imported malaria in Europe. Malar J 11:328

Babaie J, Barati M, Azizi M, Ephtekhari A, Sadat SJ (2018) A systematic evidence review of the effect of climate change on malaria in Iran. J Parasit Dis 42:331-340
Baker-Austin C, Trinanes JA, Taylor NG, Hartnell R, Siitonen A, Martinez-Urtaza J (2013) Emerging Vibrio risk at high latitudes in response to ocean warming. Nat Clim Chang 3:73-77

Ballart C, Barón S, Alcover M, Portús M, Gállego M (2012) Distribution of phlebotomine sand flies (Diptera: Psychodidae) in Andorra: first finding of P. perniciosus and wide distribution of P. ariasi. Acta Trop 122:155-159

Baylis M (2017) Potential impact of climate change on emerging vectorborne and other infections in the UK. Environ Health 16:112

Beesley N, Caminade C, Charlier J, Flynn R, Hodgkinson J, MartinezMoreno A, Martinez-Valladares M, Perez J, Rinaldi L, Williams D (2018) Fasciola and fasciolosis in ruminants in Europe: identifying research needs. Transbound Emerg Dis 65:199-216

Ben Ari T, Gershunov A, Gage KL, Snäll T, Ettestad P, Kausrud KL, Stenseth NC (2008) Human plague in the USA: the importance of regional and local climate. Biol Lett 4:737-740

Bern C, Montgomery SP, Herwaldt BL, Rassi A, Marin-Neto JA, Dantas RO, Maguire JH, Acquatella H, Morillo C, Kirchhoff LV (2007) Evaluation and treatment of Chagas disease in the United States: a systematic review. Jama 298:2171-2181

Berthová L, Slobodník V, Slobodník R, Olekšák M, Sekeyová Z, Svitálková Z, Kazimírová M, Špitalská E (2016) The natural infection of birds and ticks feeding on birds with Rickettsia spp. and Coxiella burnetii in Slovakia. Exp Appl Acarol 68:299-314

Beugnet F, Chalvet-Monfray K (2013) Impact of climate change in the epidemiology of vector-borne diseases in domestic carnivores. Comp Immunol Microbiol Infect Dis 36:559-566

Biagini P, Thèves C, Balaresque P, Geraut A, Cannet C, Keyser C, Nikolaeva D, Gerard P, Duchesne S, Orlando L (2012) Variola virus in a 300-year-old Siberian mummy

Bidle KD, Lee S, Marchant DR, Falkowski PG (2007) Fossil genes and microbes in the oldest ice on earth. Proc Natl Acad Sci 104:1345513460

Biswas G, Sankara DP, Agua-Agum J, Maiga A (2013) Dracunculiasis (guinea worm disease): eradication without a drug or a vaccine. Philosophical Transactions of the Royal Society B: Biological Sciences 368:20120146

Boecken G, Sunderkoetter C, Bogdan C, Weitzel T, Fischer M, Mueller A, Loebermann M, Anders G, Schunk M, Burchard G (2011) Diagnosis and therapy of cutaneous and mucocutaneous Leishmaniasis in Germany. Journal der Deutschen Dermatologischen Gesellschaft= journal of the German Society of Dermatology 9:1-51

Boissier J, Moné H, Mitta G, Bargues MD, Molyneux D, Mas-Coma S (2015) Schistosomiasis reaches Europe. Lancet Infect Dis 15:757758

Bouchard C, Dibernardo A, Koffi J, Wood H, Leighton P, Lindsay L (2019) Augmentation du risque de maladies transmises par les tiques dans le contexte des changements climatiques et environnementaux. Relevé des Maladies Transmissibles au Canada 45:89-98

Brown WC, Barbet AF (2016) Persistent infections and immunity in ruminants to arthropod-borne bacteria in the family Anaplasmataceae. Annual Review of Animal Biosciences 4:177197

Caminade C, Kovats S, Rocklov J, Tompkins AM, Morse AP, ColónGonzález FJ, Stenlund H, Martens P, Lloyd SJ (2014) Impact of climate change on global malaria distribution. Proc Natl Acad Sci 111:3286-3291

Caminade C, Turner J, Metelmann S, Hesson JC, Blagrove MS, Solomon T, Morse AP, Baylis M (2017) Global risk model for vector-borne transmission of Zika virus reveals the role of El Niño 2015. Proc Natl Acad Sci 114:119-124

Cann K, Thomas DR, Salmon R, Wyn-Jones A, Kay D (2013) Extreme water-related weather events and waterborne disease. Epidemiology \& Infection 141:671-686 
Cassell JA, Middleton J, Nalabanda A, Lanza S, Head MG, Bostock J, Hewitt K, Jones CI, Darley C, Karir S (2018) Scabies outbreaks in ten care homes for elderly people: a prospective study of clinical features, epidemiology, and treatment outcomes. Lancet Infect Dis 18:894-902

CDC (2017a) The Centers for Disease Control and Prevention The burden of schistosomiasis (schisto, bilharzia, snail fever)

CDC (2017b) Centers for Disease Control and Prevention parasitesonchocerciasis (also known as river blindness). Epidemiology and risk factors

CE TKVDM (2007) Higgs S A single mutation in chikungunya virus affects vector specificity and epidemic potential. PLoS Pathog 3: e201

Chandler DJ, Fuller LC (2019) A review of scabies: an infestation more than skin deep. Dermatology 235:79-90

Chénier S, Côté G, Vanderstock J, Macieira S, Laperle A, Hélie P (2010) An eastern equine encephalomyelitis (EEE) outbreak in Quebec in the fall of 2008. The Canadian Veterinary Journal 51:1011

Control CfD, Prevention (2013) Lymphatic filariasis: epidemiology and risk factors. Diakses pada

Cull B, Pietzsch ME, Hansford KM, Gillingham EL, Medlock JM (2018) Surveillance of British ticks: an overview of species records, host associations, and new records of Ixodes ricinus distribution. Ticks and Tick-Borne Diseases 9:605-614

Daniel M, Danielova V, Křŕž B, Jirsa A, Nožička J (2003) Shift of the tick Ixodes ricinus and tick-borne encephalitis to higher altitudes in central Europe. Eur J Clin Microbiol Infect Dis 22:327-328

Danis K, Baka A, Lenglet A, Van Bortel W, Terzaki I, Tseroni M, Detsis M, Papanikolaou E, Balaska A, Gewehr S (2011) Autochthonous Plasmodium vivax malaria in Greece, 2011. Eurosurveillance 16: 19993

Dantas-Torres F (2015) Climate change, biodiversity, ticks and tick-borne diseases: the butterfly effect. International Journal for Parasitology: Parasites and Wildlife 4:452-461

De Gentile L, Picot H, Bourdeau P, Bardet R, Kerjan A, Piriou M, Le Guennic A, Bayssade-Dufour C, Chabasse D, Mott KE (1996) La dermatite cercarienne en Europe: un problème de santé publique nouveau? Bull World Health Organ 74:159

Dekoninck W, Hendrickx F, Van Bortel W, Versteirt V, Coosemans M, Damiens D, Hance T, De Clercq EM, Hendrickx G, Schaffner F (2011) Human-induced expanded distribution of Anopheles plumbeus, experimental vector of West Nile virus and a potential vector of human malaria in Belgium. J Med Entomol 48:924-928

Dereure J, Vanwambeke SO, Malé P, Martinez S, Pratlong F, Balard Y, Dedet J-P (2009) The potential effects of global warming on changes in canine leishmaniasis in a focus outside the classical area of the disease in southern France. Vector-Borne and Zoonotic Diseases 9: 687-694

Dhar-Chowdhury P, Paul KK, Haque CE, Hossain S, Lindsay LR, Dibernardo A, Brooks WA, Drebot MA (2017) Dengue seroprevalence, seroconversion and risk factors in Dhaka, Bangladesh. PLoS Negl Trop Dis 11:e005475

Dhimal M, Ahrens B, Kuch U (2015a) Climate change and spatiotemporal distributions of vector-borne diseases in Nepal-a systematic synthesis of literature. PLoS One 10:e0129869

Dhimal M, Gautam I, Joshi HD, O'Hara RB, Ahrens B, Kuch U (2015b) Risk factors for the presence of chikungunya and dengue vectors (Aedes aegypti and Aedes albopictus), their altitudinal distribution and climatic determinants of their abundance in central Nepal. PLoS Neglect Tropic Dis 9

Dikid T, Jain S, Sharma A, Kumar A, Narain J (2013) Emerging \& reemerging infections in India: an overview. Indian J Med Res 138:19

Dujardin J-C, Campino L, Cañavate C, Dedet J-P, Gradoni L, Soteriadou K, Mazeris A, Ozbel Y, Boelaert M (2008) Spread of vector-borne diseases and neglect of Leishmaniasis, Europe. Emerg Infect Dis 14: 1013-1018
ECDC (2013): Phlebotomine sandflies: distribution maps Stockholm: European Centre for Disease Prevention and Control

Eisen RJ, Eisen L (2018) The blacklegged tick, Ixodes scapularis: an increasing public health concern. Trends Parasitol 34:295-309

El-Sayed A (2018) Advances in rabies prophylaxis and treatment with emphasis on immunoresponse mechanisms. International Journal of Veterinary Science and Medicine 6:8-15

El-Sayed A, Awad W (2018) Brucellosis: evolution and expected comeback. International Journal of Veterinary Science and Medicine 6: S31-S35

El-Sayed A, Ahmed S, Awad W (2008) Do camels (Camelus dromedarius) play an epidemiological role in the spread of Shiga toxin producing Escherichia coli (STEC) infection? Trop Anim Health Prod 40:469-473

Epizooties OId (2014) Terrestrial animal health code. World Organisation for Animal Health

Fatmi SS, Zehra R, Carpenter DO (2017) Powassan Virus-A New Reemerging Tick-Borne Disease. Front Public Health 5:342

Fischer D, Thomas SM, Suk JE, Sudre B, Hess A, Tjaden NB, Beierkuhnlein C, Semenza JC (2013) Climate change effects on Chikungunya transmission in Europe: geospatial analysis of vector's climatic suitability and virus' temperature requirements. Int J Health Geogr 12:51

Földvári G, Široký P, Szekeres S, Majoros G, Sprong H (2016) Dermacentor reticulatus: a vector on the rise. Parasit Vectors 9:314

Frank C, Littman M, Alpers K, Hallauer J (2006) Vibrio vulnificus wound infections after contact with the Baltic Sea, Germany. Euro Surveill 11:E060817

Gage KL, Burkot TR, Eisen RJ, Hayes EB (2008) Climate and vectorborne diseases. Am J Prev Med 35:436-450

Gaibani P, Rossini G (2017) An overview of Usutu virus. Microbes Infect 19:382-387

Gálvez R, Descalzo MA, Guerrero I, Miró G, Molina R (2011) Mapping the current distribution and predicted spread of the leishmaniosis sand fly vector in the Madrid region (Spain) based on environmental variables and expected climate change. Vector-Borne and Zoonotic Diseases 11:799-806

Garcia-Solache MA, Casadevall A (2010) Global warming will bring new fungal diseases for mammals. MBio 1:e0061-e00010

Gassner F, van Overbeek LS (2007) 12. Lyme disease in Europe: facts and no fiction. Emerging pests and vector-borne diseases in Europe, 207

Geisler WM (2012) Infections caused by Chlamydia trachomatis: including lymphogranuloma venereum, Netter's infectious diseases. Elsevier, pp. 335-343

Ghazali D, Guericolas M, Thys F, Sarasin F, Arcos Gonzalez P, Casalino E (2018) Climate change impacts on disaster and emergency medicine focusing on mitigation disruptive effects: an international perspective. Int J Environ Res Public Health 15:1379

Gilbert L (2010) Altitudinal patterns of tick and host abundance: a potential role for climate change in regulating tick-borne diseases? Oecologia 162:217-225

Gilbert L (2016) Louping ill virus in the UK: a review of the hosts, transmission and ecological consequences of control. Exp Appl Acarol 68:363-374

Gould EA, Higgs S (2009) Impact of climate change and other factors on emerging arbovirus diseases. Trans R Soc Trop Med Hyg 103:109 121

Greenblatt C, Davis A, Clement B, Kitts C, Cox T, Cano RJ (1999) Diversity of microorganisms isolated from amber. Microb Ecol 38: $58-68$

Greer A, Ng V, Fisman D (2008) Climate change and infectious diseases in North America: the road ahead. Cmaj 178:715-722

Gunda R, Chimbari MJ, Shamu S, Sartorius B, Mukaratirwa S (2017) Malaria incidence trends and their association with climatic variables in rural Gwanda, Zimbabwe, 2005-2015. Malar J 16:393 
Haines A, Patz JA (2004) Health effects of climate change. Jama 291:99 103

Hakalahti T, Karvonen A, Valtonen E (2006) Climate warming and disease risks in temperate regions-Argulus coregoni and Diplostomum spathaceum as case studies. J Helminthol 80:93-98

Hampson K, Coudeville L, Lembo T, Sambo M, Kieffer A, Attlan M, Barrat J, Blanton JD, Briggs DJ, Cleaveland S (2015) Estimating the global burden of endemic canine rabies PLoS neglected tropical diseases 9

Handmer J, Honda Y, Kundzewicz ZW, Arnell N, Benito G, Hatfield J, Mohamed IF, Peduzzi P, Wu S, Sherstyukov B (2012) Changes in impacts of climate extremes: human systems and ecosystems, managing the risks of extreme events and disasters to advance climate change adaptation special report of the intergovernmental panel on climate change. Intergovernmental Panel on Climate Change, pp 231-290

Hansen A, Cameron S, Liu Q, Sun Y, Weinstein P, Williams C, Han G-S, Bi P (2015) Transmission of haemorrhagic fever with renal syndrome in China and the role of climate factors: a review. Int $\mathrm{J}$ Infect Dis 33:212-218

Hargrove JW (2004) Tsetse population dynamics. The trypanosomiases 2004:139-180

Hartemink N, Takken W (2016) Trends in tick population dynamics and pathogen transmission in emerging tick-borne pathogens in Europe: an introduction. Exp Appl Acarol 68:269-278

Harvell C, Kim K, Burkholder J, Colwell R, Epstein PR, Grimes D, Hofmann E, Lipp E, Osterhaus A, Overstreet RM (1999) Emerging marine diseases-climate links and anthropogenic factors. Science 285:1505-1510

Hayes ML, Bonaventura J, Mitchell TP, Prospero JM, Shinn EA, Van Dolah F, Barber RT (2001) How are climate and marine biological outbreaks functionally linked?, The ecology and etiology of newly emerging marine diseases. Springer, pp 213-220

Hofhuis A, Harms M, van den Wijngaard C, Sprong H, van Pelt W (2015) Continuing increase of tick bites and Lyme disease between 1994 and 2009. Ticks and Tick-Borne Diseases 6:69-74

Holbrook, MR (2012) Kyasanur forest disease. Antivir Res 96(3):353362

Huizinga H, McLaughlin G (1990) Thermal ecology of Naegleria fowleri from a power plant cooling reservoir. Appl Environ Microbiol 56: 2200-2205

IPC C (2001): Climate change 2001: synthesis report. Intergovernmental Panel on Climate Change (IPCC), Geneva, Switzerland

IPPC 2017: Third assessment Report

Ivanescu L, Bodale I, Florescu S-A, Roman C, Acatrinei D, Miron L (2016) Climate change is increasing the risk of the reemergence of malaria in Romania. Biomed Res Int 2016:1-7

Jado I, Oteo JA, Aldámiz M, Gil H, Escudero R, Ibarra V, Portu J, Portillo A, Lezaun MJ, García-Amil C (2007) Rickettsia monacensis and human disease, Spain. Emerg Infect Dis 13:1405-1407

Jaenson TG, Hjertqvist M, Bergström T, Lundkvist $\AA$ (2012) Why is tickborne encephalitis increasing? A review of the key factors causing the increasing incidence of human TBE in Sweden. Parasit Vectors $5: 184$

Jimenez-Clavero MA (2012) Animal viral diseases and global change: bluetongue and West Nile fever as paradigms. Front Genet 3:105

Jore S, Viljugrein H, Hofshagen M, Brun-Hansen H, Kristoffersen AB, Nygård K, Brun E, Ottesen P, Sævik BK, Ytrehus B (2011) Multisource analysis reveals latitudinal and altitudinal shifts in range of Ixodes ricinus at its northern distribution limit. Parasit Vectors 4:84

June C (2018) www.cbc.ca/news/canada/windsor/mosquito-trapcaptures-known-carriers-zika-virus- 1.4693081

Katayama T, Tanaka M, Moriizumi J, Nakamura T, Brouchkov A, Douglas TA, Fukuda M, Tomita F, Asano K (2007) Phylogenetic analysis of bacteria preserved in a permafrost ice wedge for 25,000 years. Appl Environ Microbiol 73:2360-2363
Kawahara M, Rikihisa Y, Isogai E, Takahashi M, Misumi H, Suto C, Shibata S, Zhang C, Tsuji M (2004) Ultrastructure and phylogenetic analysis of 'Candidatus Neoehrlichia mikurensis' in the family Anaplasmataceae, isolated from wild rats and found in Ixodes ovatus ticks. Int J Syst Evol Microbiol 54:1837-1843

Kazimírová M, Thangamani S, Bartíková P, Hermance M, Holíková V, Štibrániová I, Nuttall PA (2017) Tick-borne viruses and biological processes at the tick-host-virus interface. Front Cell Infect Microbiol $7: 339$

Kernif T, Leulmi H, Raoult D, Parola P (2016) Emerging tick-borne bacterial pathogens. Emerging Infections 10:295-310

Kilpatrick AM, Kramer LD, Jones MJ, Marra PP, Daszak P (2006) West Nile virus epidemics in North America are driven by shifts in mosquito feeding behavior. PLoS Biol 4:e82

Koehler LM, Kloppert B, Hamann H-P, El-Sayed A, Zschöck M (2019) Comprehensive literature review of the sources of infection and transmission routes of Coxiella burnetii, with particular regard to the criteria of "evidence-based medicine". Comp Immunol Microbiol Infect Dis 64:67-72

Kolarova L (2007) Schistosomes causing cercarial dermatitis: a minireview of current trends in systematics and of host specificity and pathogenicity. Folia Parasitol 54:81-87

Krüger A, Rech A, Su XZ, Tannich E (2001) Two cases of autochthonous Plasmodium falciparum malaria in Germany with evidence for local transmission by indigenous Anopheles plumbeus. Tropical Med Int Health 6:983-985

Kuhn KG, Campbell-Lendrum DH, Armstrong B, Davies CR (2003) Malaria in Britain: past, present, and future. Proc Natl Acad Sci 100:9997-10001

Kulkarni MA, Berrang-Ford L, Buck PA, Drebot MA, Lindsay LR, Ogden NH (2015) Major emerging vector-borne zoonotic diseases of public health importance in Canada. Emerging Microbes \& Infections 4:1-7

Larsen A, Bresciani J, Buchmann K (2004) Increasing frequency of cercarial dermatitis at higher latitudes. Acta Parasitol 49

Leistner R, Buchwald D, Beyer M, Philipp S (2017) Scabies outbreak among healthcare workers in a German acute care hospital. J Infect Prev 18:189-192

Lindgren E (2000) L. Talleklint, 1'. Polfeldt. Environ. Health Perspect 108:119

Lindgren E, Gustafson R (2001) Tick-borne encephalitis in Sweden and climate change. Lancet 358:16-18

Lu P, Zhou Y, Yu Y, Cao J, Zhang H, Gong H, Li G, Zhou J (2016) RNA interference and the vaccine effect of a subolesin homolog from the tick Rhipicephalus haemaphysaloides. Exp Appl Acarol 68:113126

Ludwig A, Zheng H, Vrbova L, Drebot M, Iranpour M, Lindsay L (2019) Climate change and infectious diseases: the challenges: increased risk of endemic mosquito-borne diseases in Canada due to climate change. Can Commun Dis Rep 45:91-97

Lukan M, Bullova E, Petko B (2010) Climate warming and tick-borne encephalitis, Slovakia. Emerg Infect Dis 16:524-526

Mackey TK, Liang BA, Cuomo R, Hafen R, Brouwer KC, Lee DE (2014) Emerging and reemerging neglected tropical diseases: a review of key characteristics, risk factors, and the policy and innovation environment. Clin Microbiol Rev 27:949-979

Majoros G, Fehér Z, Deli T, Földvári G (2008) Establishment of Biomphalaria tenagophila snails in Europe. Emerg Infect Dis 14: 1812-1814

Mannelli A, Bertolotti L, Gern L, Gray J (2012) Ecology of Borrelia burgdorferi sensu lato in Europe: transmission dynamics in multihost systems, influence of molecular processes and effects of climate change. FEMS Microbiol Rev 36:837-861

Mansfield K, Johnson N, Phipps L, Stephenson J, Fooks A, Solomon T (2009) Tick-borne encephalitis virus-a review of an emerging zoonosis. J Gen Virol 90:1781-1794 
Marcogliese D (2008) The impact of climate change on the parasites and infectious diseases of aquatic animals. Rev Sci Tech 27:467-484

Mas-Coma S, Valero M, Bargues M (2008) Effects of climate change on animal and zoonotic helminthiases. Rev Sci Tech 27:443-457

McCarthy JJ, Canziani OF, Leary NA, Dokken DJ, White KS (2001) Climate change 2001: impacts, adaptation, and vulnerability: contribution of Working Group II to the third assessment report of the Intergovernmental Panel on Climate Change, 2. Cambridge University Press

McMullan LK, Folk SM, Kelly AJ, MacNeil A, Goldsmith CS, Metcalfe MG, Batten BC, Albariño CG, Zaki SR, Rollin PE, Nicholson WL, Nichol ST (2012) A New Phlebovirus Associated with Severe Febrile Illness in Missouri. N Engl J Med 367 (9):834-841

Medialdea-Carrera R, Melillo T, Gauci C, Rocco G, Borg ML (2018) Letter to the editor: Is malaria re-emerging in southern Europe? Cryptic Plasmodium falciparum malaria in Malta, October 2018. Eurosurveillance 23

Medone P, Ceccarelli S, Parham PE, Figuera A, Rabinovich JE (2015) The impact of climate change on the geographical distribution of two vectors of Chagas disease: implications for the force of infection. Philosophical Transactions of the Royal Society B: Biological Sciences 370:20130560

Merhej V, Angelakis E, Socolovschi C, Raoult D (2014) Genotyping, evolution and epidemiological findings of rickettsia species. Infect Genet Evol 25:122-137

Micallef MJ (2016) The Roman fever: observations on the understanding of malaria in the ancient Roman world. Geographica 5:7

Milazzo A, Giles LC, Zhang Y, Koehler AP, Hiller JE, Bi P (2017) Factors influencing knowledge, food safety practices and food preferences during warm weather of Salmonella and Campylobacter cases in South Australia. Foodborne Pathog Dis 14:125-131

Min J-G, Xue M (1996) Progress in studies on the overwintering of the mosquito Culex tritaeniorhynchus. The Southeast Asian Journal of Tropical Medicine and Public Health 27:810-817

Mitra AK, Mawson AR (2017) Neglected tropical diseases: epidemiology and global burden. Tropical Medicine and Infectious Disease 2: 36

Molyneux E (2009) Emergency care for children in resource-constrained countries. Trans R Soc Trop Med Hyg 103:11-15

Monge-Maillo B, López-Vélez R (2012) Migration and malaria in Europe. Mediterranean Journal of Hematology and Infectious Diseases 4:e2012014

Moore S, Shrestha S, Tomlinson KW, Vuong H (2011) Predicting the effect of climate change on African trypanosomiasis: integrating epidemiology with parasite and vector biology. J R Soc Interface 9:817-830

Moore S, Shrestha S, Tomlinson KW, Vuong H (2012) Predicting the effect of climate change on African trypanosomiasis: integrating epidemiology with parasite and vector biology. J R Soc Interface 9:817-830

Mor S, Walsh M, Willem de Smalen A (2018) Climatic influence on anthrax suitability in warming northern latitudes

Morgan J, Dejong R, Snyder S, Mkoji G, Loker E (2001) Schistosoma mansoni and Biomphalaria: past history and future trends. Parasitology 123:211-228

Nakazawa Y, Williams R, Peterson AT, Mead P, Staples E, Gage KL (2007) Climate change effects on plague and tularemia in the United States. Vector-Borne and Zoonotic Diseases 7:529-540

Nava A, Shimabukuro JS, Chmura AA, Luz SLB (2017) The impact of global environmental changes on infectious disease emergence with a focus on risks for Brazil. ILAR J 58:393-400

Neghina R, Neghina AM, Marincu I, Iacobiciu I (2011) International travel increase and malaria importation in Romania, 2008-2009. Vector-Borne and Zoonotic Diseases 11:1285-1288

$\mathrm{Ng} \mathrm{V}$, Rees E, Lindsay L, Drebot M, Brownstone T, Sadeghieh T, Khan S (2019) Climate change and infectious diseases: the challenges: could exotic mosquito-borne diseases emerge in Canada with climate change? Can Commun Dis Rep 45:98-107

Nicolescu G, Purcarea-Ciulacu V, Vladimirescu A, Dumitrescu G, Saizu D, Savin E, Sandric I, Mihai F (2016) Could malaria re-emerge in Romania? Int J Infect Dis 45:187-188

Ogden N, Gachon P (2019) Climate change and infectious diseases: the challenges: climate change and infectious diseases: what can we expect? Can Commun Dis Rep 45:76-80

Ogden NH, Lindsay LR (2016) Effects of climate and climate change on vectors and vector-borne diseases: ticks are different. Trends Parasitol 32:646-656

Ogden NH, Milka R, Caminade C, Gachon P (2014) Recent and projected future climatic suitability of North America for the Asian tiger mosquito Aedes albopictus. Parasit Vectors 7:532

Organization WH (2005) Using climate to predict infectious disease epidemics

Organization WH (2018) COP24 special report: health and climate change

Pacheco RC, Echaide IE, Alves RN, Beletti ME, Nava S, Labruna MB (2013) Coxiella burnetii in ticks, Argentina. Emerg Infect Dis 19: 344-346

Paddock CD, Childs JE (2003) Ehrlichia chaffeensis: a prototypical emerging pathogen. Clin Microbiol Rev 16:37-64

Paddock CD, Goddard J (2015) The evolving medical and veterinary importance of the Gulf coast tick (Acari: Ixodidae). J Med Entomol 52:230-252

Papa A, Mirazimi A, Köksal I, Estrada-Pena A, Feldmann H (2015) Recent advances in research on Crimean-Congo hemorrhagic fever. J Clin Virol 64:137-143

Park MS, Park KH, Bahk GJ (2018) Interrelationships between multiple climatic factors and incidence of foodborne diseases. Int J Environ Res Public Health 15:2482

Parola P, Raoult D (2001) Tick-borne bacterial diseases emerging in Europe. Clin Microbiol Infect 7:80-83

Parola P, Paddock CD, Raoult D (2005) Tick-borne rickettsioses around the world: emerging diseases challenging old concepts. Clin Microbiol Rev 18:719-756

Parola P, Socolovschi C, Jeanjean L, Bitam I, Fournier P-E, Sotto A, Labauge P, Raoult D (2008) Warmer weather linked to tick attack and emergence of severe rickettsioses. PLoS neglected tropical diseases 2

Pascual M, Rodó X, Ellner SP, Colwell R, Bouma MJ (2000) Cholera dynamics and El Nino-southern oscillation. Science 289:1766-1769

Paz S (2015) Climate change impacts on West Nile virus transmission in a global context. Philosophical Transactions of the Royal Society B: Biological Sciences 370:20130561

Pijnacker R, Goris MG, Te Wierik MJ, Broens EM, van der Giessen JW, de Rosa M, Wagenaar JA, Hartskeerl RA, Notermans DW, Maassen $\mathrm{K}$ (2016) Marked increase in leptospirosis infections in humans and dogs in the Netherlands, 2014. Eurosurveillance 21

Pointier J, David P, Jarne P (2005) Biological invasions: the case of planorbid snails. J Helminthol 79:249-256

Porretta D, Mastrantonio V, Amendolia S, Gaiarsa S, Epis S, Genchi C, Bandi C, Otranto D, Urbanelli S (2013) Effects of global changes on the climatic niche of the tick Ixodes ricinus inferred by species distribution modelling. Parasit Vectors 6:271

Portier C, Thigpen TK, Carter S, Dilworth C, Grambsch A, Gohlke J, Hess J, Howard S, Luber G, Lutz J (2017) A human health perspective on climate change: a report outlining the research needs on the human health effects of climate change. Environmental Health Perspectives/National Institute of Environmental Health

Powell JR (2018) Mosquito-borne human viral diseases: why Aedes aegypti? The American Journal of Tropical Medicine and Hygiene 98:1563-1565

Prudhomme J, Fontaine A, Lacour G, Gantier J-C, Diancourt L, Velo E, Bino S, Reiter P, Mercier A (2019) The native European Aedes 
geniculatus mosquito species can transmit chikungunya virus. Emerging Microbes \& Infections 8:962-972

Purse BV, Mellor PS, Rogers DJ, Samuel AR, Mertens PP, Baylis M (2005) Climate change and the recent emergence of bluetongue in Europe. Nat Rev Microbiol 3:171-181

Ramos JM, Romero D, Belinchon I (2016) Epidemiology of leprosy in Spain: the role of the international migration. PLoS neglected tropical diseases 10

Randolph SE (2004) Evidence that climate change has caused 'emergence'of tick-borne diseases in Europe? International Journal of Medical Microbiology Supplements 293:5-15

Ready P (2010) Leishmaniasis emergence in Europe. Eurosurveillance 15:19505

Redshaw CH, Stahl-Timmins WM, Fleming LE, Davidson I, Depledge MH (2013) Potential changes in disease patterns and pharmaceutical use in response to climate change. Journal of Toxicology and Environmental Health, Part B 16:285-320

Renn O, Klinke A, Van Asselt M (2011) Coping with complexity, uncertainty and ambiguity in risk governance: a synthesis. Ambio 40: 231-246

Report W (2015) Yellow Fever. https://www.who.int/news-room/factsheets/detail/yellow-fever

Rezza G, Nicoletti L, Angelini R, Romi R, Finarelli A, Panning M, Cordioli P, Fortuna C, Boros S, Magurano F (2007) Infection with chikungunya virus in Italy: an outbreak in a temperate region. Lancet 370:1840-1846

Ricciardi A (2006) Patterns of invasion in the Laurentian Great Lakes in relation to changes in vector activity. Divers Distrib 12:425-433

Rizzoli A, Hauffe HC, Carpi G, Vourc'h G, Neteler M, Rosa R (2011) Lyme borreliosis in Europe. Eurosurveillance 16:19906

Rose JB, Epstein PR, Lipp EK, Sherman BH, Bernard SM, Patz JA (2001) Climate variability and change in the United States: potential impacts on water-and foodborne diseases caused by microbiologic agents. Environ Health Perspect 109:211-221

Sallares R (2002) Malaria and Rome: a history of malaria in ancient Italy. Oxford University Press on Demand

Sanyaolu A, Okorie C, Badaru O, Wynveen E, White S, Wallace W (2016) Chikungunya epidemiology: a global perspective. SM J Public Health Epidemiol 2:1028

Schets F, Van den Berg H, Demeulmeester A, Van Dijk E, Rutjes S, Van Hooijdonk H, de Roda Husman A (2006) Vibrio alginolyticus infections in the Netherlands after swimming in the North Sea. Weekly Releases (1997-2007) 11:3077

Schmidt JP, Park AW, Kramer AM, Han BA, Alexander LW, Drake JM (2017) Spatiotemporal fluctuations and triggers of Ebola virus spillover. Emerg Infect Dis 23:415-422

Scholte E, Den Hartog W, Dik M, Schoelitsz B, Brooks M, Schaffner F, Foussadier R, Braks M, Beeuwkes J (2010) Introduction and control of three invasive mosquito species in the Netherlands, July-October 2010. Eurosurveillance 15:19710

Semenza JC, Herbst S, Rechenburg A, Suk JE, Höser C, Schreiber C, Kistemann T (2012) Climate change impact assessment of food-and waterborne diseases. Crit Rev Environ Sci Technol 42:857-890

Shikanai-Yasuda MA, Carvalho NB (2012) Oral transmission of Chagas disease. Clin Infect Dis 54:845-852

Smith KR, Woodward A, Campbell-Lendrum D, Chadee DD, Honda Y, Liu Q, Olwoch JM, Revich B, Sauerborn R, Field C (2017) Human health: impacts, adaptation and co-benefits

Solomon S, Qin D, Manning M, Chen Z, Marquis M, Averyt K, Tignor M, Miller H (2007) IPCC fourth assessment report (AR4). Climate change

Sonenshine DE (2018) Range expansion of tick disease vectors in North America: implications for spread of tick-borne disease. Int J Environ Res Public Health 15:478

Sousa C, Clairouin M, Seixas G, Viveiros B, Novo M, Silva A, Escoval M, Economopoulou A (2012) Ongoing outbreak of dengue type 1 in the Autonomous Region of Madeira, Portugal: preliminary report. Eurosurveillance 17:20333

Ssempiira J, Kissa J, Nambuusi B, Mukooyo E, Opigo J, Makumbi F, Kasasa S, Vounatsou P (2018) Interactions between climatic changes and intervention effects on malaria spatio-temporal dynamics in Uganda. Parasite Epidemiology and Control 3:e00070

Stuen S, Granquist EG, Silaghi C (2013) Anaplasma phagocytophiluma widespread multi-host pathogen with highly adaptive strategies. Front Cell Infect Microbiol 3:31

Sykora J, Keleti G, Martinez AJ (1983) Occurrence and pathogenicity of Naegleria fowleri in artificially heated waters. Appl Environ Microbiol 45:974-979

Talapko J, Škrlec I, Alebić T, Jukić M, Včev A (2019) Malaria: the past and the present. Microorganisms 7:179

Teklehaimanot HD, Schwartz J, Teklehaimanot A, Lipsitch M (2004) Alert threshold algorithms and malaria epidemic detection. Emerg Infect Dis 10:1220-1226

Thomas RJ, Dumler JS, Carlyon JA (2009) Current management of human granulocytic anaplasmosis, human monocytic ehrlichiosis and Ehrlichia ewingii ehrlichiosis. Expert Rev Anti-Infect Ther 7:709 722

Thompson AA, Matamale L, Kharidza SD (2012) Impact of climate change on children's health in Limpopo Province, South Africa. Int J Environ Res Public Health 9:831-854

Tokarevich NK, Tronin AA, Blinova OV, Buzinov RV, Boltenkov VP, Yurasova ED, Nurse J (2011) The impact of climate change on the expansion of Ixodes persulcatus habitat and the incidence of tickborne encephalitis in the north of European Russia. Glob Health Action 4:8448

Tokarz R, Williams SH, Sameroff S, Leon MS, Jain K, Lipkin WI (2014) Virome analysis of Amblyomma americanum, Dermacentor variabilis, and Ixodes scapularis ticks reveals novel highly divergent vertebrate and invertebrate viruses. J Virol 88:11480-11492

Tokarz R, Sameroff S, Tagliafierro T, Jain K, Williams SH, Cucura DM, Rochlin I, Monzon J, Carpi G, Tufts D (2018) Identification of novel viruses in Amblyomma americanum, Dermacentor variabilis, and Ixodes scapularis ticks. Msphere 3:e0614-e0617

Tong C, Javelle E, Grard G, Dia A, Lacrosse C, Fourié T, Gravier P, Watier-Grillot S, Lancelot R, Letourneur F (2019) Tracking Rift Valley fever: from Mali to Europe and other countries, 2016. Eurosurveillance 24

Touchon M, Hoede C, Tenaillon O, Barbe V, Baeriswyl S, Bidet P, et al. (2009) Organised genome dynamics in the Escherichia coli species results in highly diverse adaptive paths. PLoS Genet 5, e1000344

Vannier E, Krause PJ (2012) Human babesiosis. N Engl J Med 366:2397_ 2407

Vannier E, Krause PJ (2020) Babesiosis, Hunter's tropical medicine and emerging infectious diseases. Elsevier, pp 799-802

Vazquez A, Jiménez-Clavero M, Franco L, Donoso-Mantke O, Sambri V, Niedrig M, Zeller H, Tenorio A (2011) Usutu virus-potential risk of human disease in Europe. Eurosurveillance 16:19935

Walsh AS, Glass GE, Lesser CR, Curriero FC (2008) Predicting seasonal abundance of mosquitoes based on off-season meteorological conditions. Environ Ecol Stat 15:279-291

WHO (2017): (WHO report 2017: Global environmental change

Wikel SK (2018) Ticks and tick-borne infections: complex ecology, agents, and host interactions. Veterinary Sciences 5:60

Ziegler U, Lühken R, Keller M, Cadar D, Van Der Grinten E, Michel F, Albrecht K, Eiden M, Rinder M, Lachmann L (2019) West Nile virus epizootic in Germany, 2018. Antivir Res 162:39-43

Publisher's note Springer Nature remains neutral with regard to jurisdictional claims in published maps and institutional affiliations. 